\title{
Prorubricyte Count
}

National Cancer Institute

\section{Source}

National Cancer Institute. Prorubricyte Count. NCI Thesaurus. Code C128976.

The determination of the amount of prorubricytes present in a sample. 